\title{
Angiotensin II type 2 receptor overexpression activates the vascular kinin system and causes vasodilation
}

\author{
Yoshiaki Tsutsumi, ${ }^{1}$ Hiroaki Matsubara, ${ }^{1}$ Hiroya Masaki, ${ }^{1,2}$ Hiroki Kurihara,${ }^{3}$ \\ Satoshi Murasawa, ${ }^{1}$ Shinji Takai, ${ }^{4}$ Mizuo Miyazaki, ${ }^{4}$ Yoshihisa Nozawa, ${ }^{5}$ Ryoji Ozono, ${ }^{6}$ \\ Keigo Nakagawa, ${ }^{6}$ Takeshi Miwa, ${ }^{7}$ Noritaka Kawada, ${ }^{7}$ Yasukiyo Mori, ${ }^{1}$ \\ Yasunobu Shibasaki, ${ }^{1}$ Yohko Tanaka, ${ }^{1}$ Soichiro Fujiyama, ${ }^{1}$ Yohko Koyama, ${ }^{1}$ \\ Atsuko Fujiyama, ${ }^{1}$ Hakuo Takahashi, ${ }^{2}$ and Toshiji Iwasaka ${ }^{1}$ \\ ${ }^{1}$ Department of Medicine II, and \\ ${ }^{2}$ Department of Laboratory Medicine and Clinical Sciences, Kansai Medical University, Moriguchi, Osaka 570, Japan \\ ${ }^{3}$ Suntory Institute for Biomedical Research, Mishimagun 618, Japan \\ ${ }^{4}$ Department of Pharmacology, Osaka Medical College, Takatsuki 569, Japan \\ ${ }^{5}$ Pharmacological Laboratory, Taiho Pharmaceutical Co. Ltd., Tokushima 771, Japan \\ ${ }^{6}$ Department of Laboratory Medicine, Hiroshima University, Hiroshima 734, Japan \\ ${ }^{7}$ Genome Information Center, Osaka University, Suita 565, Japan \\ Address correspondence to: Hiroaki Matsubara, Department of Medicine II, Kansai Medical University, \\ Fumizonocho 10-15, Moriguchi, Osaka 570-8507, Japan. Fax: 81-6-6998-6178; E-mail: matsubah@takii.kmu.ac.jp.
}

Received for publication August 19, 1999, and accepted in revised form August 25, 1999.

Angiotensin II (Ang II) is a potent vasopressor peptide that interacts with 2 major receptor isoforms - AT1 and AT2. Although blood pressure is increased in AT2 knockout mice, the underlying mechanisms remain undefined because of the low levels of expression of AT2 in the vasculature. Here we overexpressed AT2 in vascular smooth muscle (VSM) cells in transgenic (TG) mice. Aortic AT1 was not affected by overexpression of AT2. Chronic infusion of Ang II into AT2-TG mice completely abolished the AT1-mediated pressor effect, which was blocked by inhibitors of bradykinin type 2 receptor (icatibant) and nitric oxide (NO) synthase (L-NAME). Aortic explants from TG mice showed greatly increased cGMP production and diminished Ang II-induced vascular constriction. Removal of endothelium or treatment with icatibant and L-NAME abolished these AT2-mediated effects. AT2 blocked the amiloride-sensitive $\mathrm{Na}^{+} / \mathrm{H}^{+}$exchanger, promoting intracellular acidosis in VSM cells and activating kininogenases. The resulting enhancement of aortic kinin formation in TG mice was not affected by removal of endothelium. Our results suggest that AT2 in aortic VSM cells stimulates the production of bradykinin, which stimulates the NO/cGMP system in a paracrine manner to promote vasodilation. Selective stimulation of AT2 in the presence of AT1 antagonists is predicted to have a beneficial clinical effect in controlling blood pressure.

J. Clin. Invest. 104:925-935 (1999).

\section{Introduction}

The biological effects caused by circulating angiotensin II (Ang II) are diverse and widespread, and play a critical role in regulation of the cardiovascular and renal systems (1). At least 2 main Ang II receptor subtypes - AT1 and AT2 - have been identified using receptor subtype-specific antagonists $(2,3)$. Most of the Ang II-mediated vasoconstrictive actions are mediated by AT1, whereas little information is available regarding the physiological roles of AT2 and its signal-transduction pathway (4). AT1 antagonists are currently undergoing clinical trials in patients with hypertension or heart failure. Treatment with AT1 antagonists causes elevation of plasma Ang II, which selectively binds to AT2 and exerts clinically important, but as yet undefined, effects (5). Although the level of AT2 expression is low in large vessels such as the aorta, AT2 is present at high levels in microvessels (6-8). Ichiki et al. (9) and Hein et al. (10) reported that disruption of the AT2 gene caused an increase in blood pressure (BP) and increased sensitivity to the pressor action of Ang II. Interestingly, in elderly patients with heart failure (11), selective activation of AT2 by treatment with the AT1 antagonist losartan was associated with an unexpected lower risk of mortality compared with treatment with the angiotensin-converting enzyme (ACE) inhibitor captopril. These findings suggested either a physiological role for AT2 in BP control or a cardioprotective effect, although the underlying mechanism of these effects remains poorly defined.

Involvement of the nitric oxide (NO) system in AT2mediated vascular effects has been reported in bovine endothelial cells (12), isolated rat carotid arteries (13), canine microvessels from coronary arteries (14), and rat aortic strips (15). In a rat model of heart failure due to myocardial infarction (16), the reduced cardiac function and cardiac fibrosis were improved by an AT2 antagonist and a bradykinin type 2 (BK2) receptor antagonist. Inhibition of AT2 in cardiac hypertrophy 

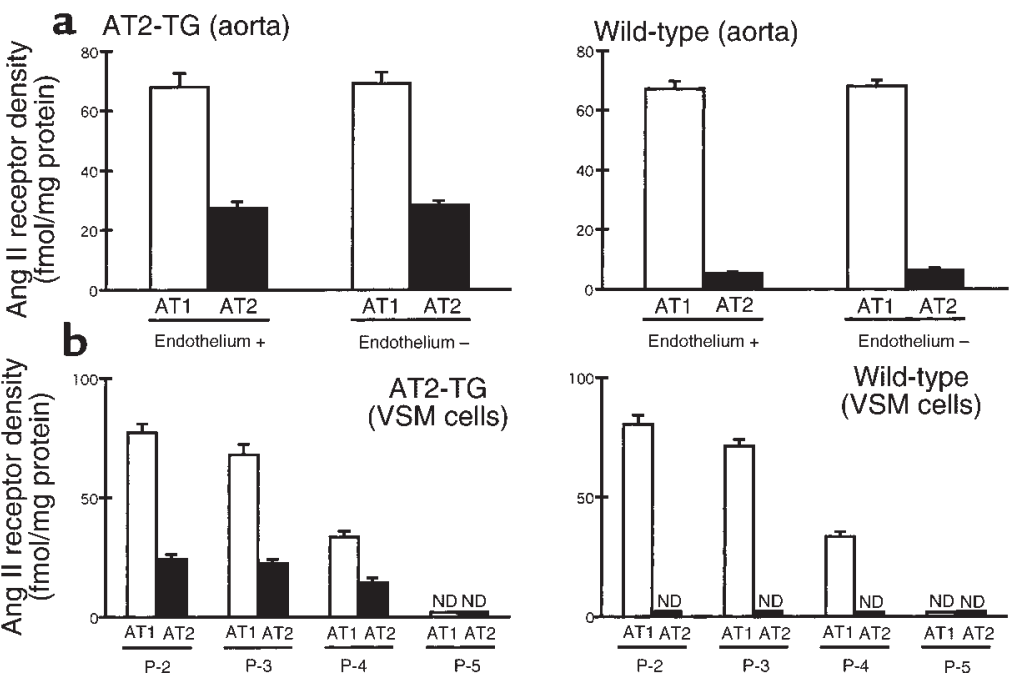

\begin{abstract}
Figure 1
Ang II receptor densities in the aorta and aortic VSM cells. (a) Aortas, including thoracic and abdominal portions, were isolated from AT2-TG and wild-type mice. Removal of endothelium was performed by gently rubbing the intimal surface with a cotton pellet. Removal of the endothelium was verified by abolishment of the relaxation by 1 $\mu \mathrm{mol} / \mathrm{L}$ acetylcholine. Membrane fractions were prepared from the pooled samples $(n=10)$, and aortic Ang II receptor densities were separately measured 3 times. (b) Aortic VSM cells ( $n=4$ each) were obtained primarily by the explant method (P0 ) and passaged with trypsin (P-2 to P-5). Ang II receptor densities were measured by the ligandbinding assay described in Methods. Results are expressed as means \pm SE. ND, not detected.
\end{abstract}

amplifies the growth response of the left ventricle through suppression of cGMP signaling (17). In strokeprone spontaneously hypertensive rats (18), aortic cGMP production stimulated by Ang II infusion was inhibited by AT2 antagonists, as well as by a BK2 receptor antagonist or NO synthase inhibitor. In the kidney, AT2-mediated NO production was closely involved in AT2-mediated pressure natriuresis and diuresis $(19,20)$ and renal production of cGMP in response to $\mathrm{Na}^{+}$ depletion $(21,22)$. Thus, although these previous studies suggested the possible involvement of the bradykinin/NO system in AT2-mediated physiological functions, direct evidence linking AT2 to bradykinin synthesis and AT2-mediated vascular action remained poorly defined, because of the lack of a suitable experimental model overexpressing AT2 in the vascular system. Here we report the unexpected finding that vascular smooth muscle-specific (VSM-specific) overexpression of the AT2 gene, using the VSM-specific $\alpha$-actin promoter, completely abolished the Ang II-mediated pressor action and vasoconstrictive effect through an endothelium-dependent mechanism. Our results also demonstrated that AT2-mediated inhibition of acid efflux through inhibition of $\mathrm{Na}^{+} / \mathrm{H}^{+}$ exchanger activity enhances kininogenase activity in aortic VSM cells to liberate bradykinin, which causes endothelial BK2 receptor-mediated vasodilation through activation of the NO/cGMP system, resulting in an AT2-mediated depressor effect on BP control.

\section{Methods}

Transgene constructs and screening of transgenic mice. A 4.7$\mathrm{kb}$ fragment of the mouse smooth muscle $\alpha$-actin $(\mathrm{SM} \alpha \mathrm{A})$ promoter (23) and a mouse AT2 cDNA were subcloned into the plasmid pBsKS(-). The $\sim 7.5-\mathrm{kb}$ DNA fragment, consisting of the SM $\alpha$ A promoter and AT2 cDNA, was microinjected into the pronuclei of fertilized mouse embryos at the single-cell stage to generate transgenic (TG) mice (C57BL/6 strain) as reported previously (24). To detect the TG mice, we designed sense and antisense PCR primers from the $\mathrm{SM} \alpha \mathrm{A}$ and AT2-R genes, respectively.

Membrane preparation and receptor assay. The mice were sacrificed by decapitation, and the aorta, including thoracic and abdominal portions, was dissected out and minced with scissors. Membrane fractions were prepared from pooled aortic samples $(n=10)$ as described previously (24-26). Membrane fractions were incubated with different concentrations (0.05-1 nM) of [125I]Sar1, Ile8-Ang II, or [125I]CGP42112A for $120 \mathrm{~min}-$ utes at $20^{\circ} \mathrm{C}$ for the saturation experiment. Specific binding of $\left[{ }^{125} \mathrm{I}\right]$ Sar1, Ile8-Ang II, and [ $\left.{ }^{125} \mathrm{I}\right] \mathrm{CGP} 42112 \mathrm{~A}$ was determined from the difference between counts in the absence of $10 \mu \mathrm{mol} / \mathrm{L}$ AT1 antagonist (losartan) and the presence of $1 \mu \mathrm{mol} / \mathrm{L}$ AT2 antagonist (CGP42112A). The $K_{\mathrm{d}}$ and $B_{\max }$ values were estimated by Rosenthal analysis of the saturation data, and AT1 and AT2 densities were calculated from $B_{\max }$ values.

Aortic cGMP content. The cGMP was determined by a specific RIA (Amersham Pharmacia Biotech, Uppsala, Sweden) (18). Briefly, frozen aortas were weighted, pulverized in liquid nitrogen using a mortar and pestle, and transferred into $2 \mathrm{~mL}$ of ethanol. The samples were sonicated for 10 seconds at $4^{\circ} \mathrm{C}$ and centrifuged for 15 minutes at $6,000 \mathrm{~g}$. The supernatants were lyophilized and resuspended in $0.5 \mathrm{~mL}$ of sodium acetate buffer ( $0.05 \mathrm{~mol} / \mathrm{L})$ containing $0.01 \%$ sodium azide. After addition of $25 \mu \mathrm{L}$ of an acetylation reagent (1 part acetanhydrite and 2 parts triethylamine), the samples were vortexed, and aliquots of $100 \mu \mathrm{L}$ were transferred into tubes containing $100 \mu \mathrm{L}$ of antiserum (rabbit anticGMP serum). After incubation for 1 hour at $23^{\circ} \mathrm{C}, 100$ $\mu \mathrm{L}$ of the tracer $\left[{ }^{125} \mathrm{I}\right] 2^{\prime}$-o-succinyl-cGMP tyrosine methyl ester was added, and the samples were incubated for 16 hours at $4^{\circ} \mathrm{C}$. The samples were then incubated for 10 minutes with $500 \mu \mathrm{L}$ of a second antibody, and centrifuged. The supernatant was discarded, and the radioactivity in the pellet was counted in a gamma counter. The cGMP content was expressed in femtomoles per gram of protein, as measured by the Brad- 
ford method using a protein assay kit (Bio-Rad Laboratories Inc., Richmond, California, USA).

Determination of vascular constrictive response. The constrictive response of isolated aorta was determined as described previously (27). Briefly, the aorta was cut into helical strips (10 $\mathrm{mm}$ long and $1 \mathrm{~mm}$ wide). In some experiments, the endothelium was removed by gently rubbing the intimal surface with a cotton pellet. The resting tension was adjusted to $0.8 \mathrm{~g}$, which is optimal for induction of maximal contraction. The strips were equilibrated for 2 hours in bathing medium (Tyrode's solution containing [in mmol/L] $137 \mathrm{NaCl}, 2.7 \mathrm{KCl}, 1.8 \mathrm{CaCl}_{2}, 1.1$ $\mathrm{MgCl}_{2}, 0.42 \mathrm{NaH}_{2} \mathrm{PO}_{4}, 12 \mathrm{NaHCO}_{3}$, and 5.7 glucose $[\mathrm{pH}$ 7.4]) maintained at $37^{\circ} \mathrm{C}$ and continuously bubbled with $\mathrm{O}_{2} / \mathrm{CO}_{2}$ (95:5). Removal of the endothelium was verified by abolishment of the relaxation using $1 \mu \mathrm{mol} / \mathrm{L}$ acetylcholine. The contractile response to $50 \mathrm{mmol} / \mathrm{L}$ Ang II was obtained first. Then the bathing medium was washed out twice with fresh Tyrode's solution, for 15 minutes each time, and the preincubation for equilibration was performed for 30 minutes. The experiment to test the constrictive response of aorta by Ang II was repeated twice, and the third response was regarded as the control response for Ang II. Subsequently, the medium was washed out twice with fresh Tyrode's solution, for 15 minutes each time, and then the vascular response to Ang II $(50 \mathrm{nmol} / \mathrm{L})$ was recorded in the presence or absence of AT2 antagonist PD123319 $(1 \mu \mathrm{mol} / \mathrm{L})$.

Measurements of BP and heart rate. Systolic, mean, and diastolic BPs were measured using a programmable sphygmomanometer (BP-98A; Softron, Tokoyo, Japan) using the tail-cuff method described previously (28). For drug-infusion experiments, male mice (16-18 weeks old) were anesthetized with pentobarbital sodium $(50 \mathrm{mg} / \mathrm{kg}$ intraperitoneally). A cervical incision was made, the trachea was intubated, and the animal was connected to a volume-cycled ventilator. A PE10 flame-stretched, fluidfilled catheter was introduced into the femoral artery and attached to a transducer element (TXD-300; Digi-Med, Louisville, Kentucky, USA). The second cannula, using a PE10 catheter, was inserted into the femoral vein for injection of drugs. Data were registered on a chart recorder, transmitted on-line with an amplifier (BPA-200; Digi-Med), and analyzed with a computer program (System Integrator Model 200; Digi-Med) as described previously (24). Ang II (0.7 mg/kg per day), icatibant $(70 \mu \mathrm{g} / \mathrm{kg}$ per day), and PD123319 (30 mg/kg per day) were infused using an ALZET osmotic pump (model 2002; ALZA Corp., Palo Alto, California, USA). AT1 antagonist TCV116 $(10 \mathrm{mg} / \mathrm{kg}$ per day) was given orally, and LNAME $(1 \mathrm{mg} / \mathrm{mL})$ was given in drinking water.

Measurement of kininogenase activity. Tissue homogenates were prepared, and kininogenase activity was measured in vascular tissues according to the method described previously $(29,30)$. The thoracic and abdominal portions of the aorta were removed, rinsed several times with ice-cold saline, and homogenized in buffer $\mathrm{A}$, including $0.1 \mathrm{~mol} / \mathrm{L}$ phosphate buffer $(\mathrm{pH} 8.2)$, bacitracin $(0.2 \%), 1,10$-phenanthroline $(3 \mathrm{mmol} / \mathrm{L}), 8-\mathrm{OH}$ -

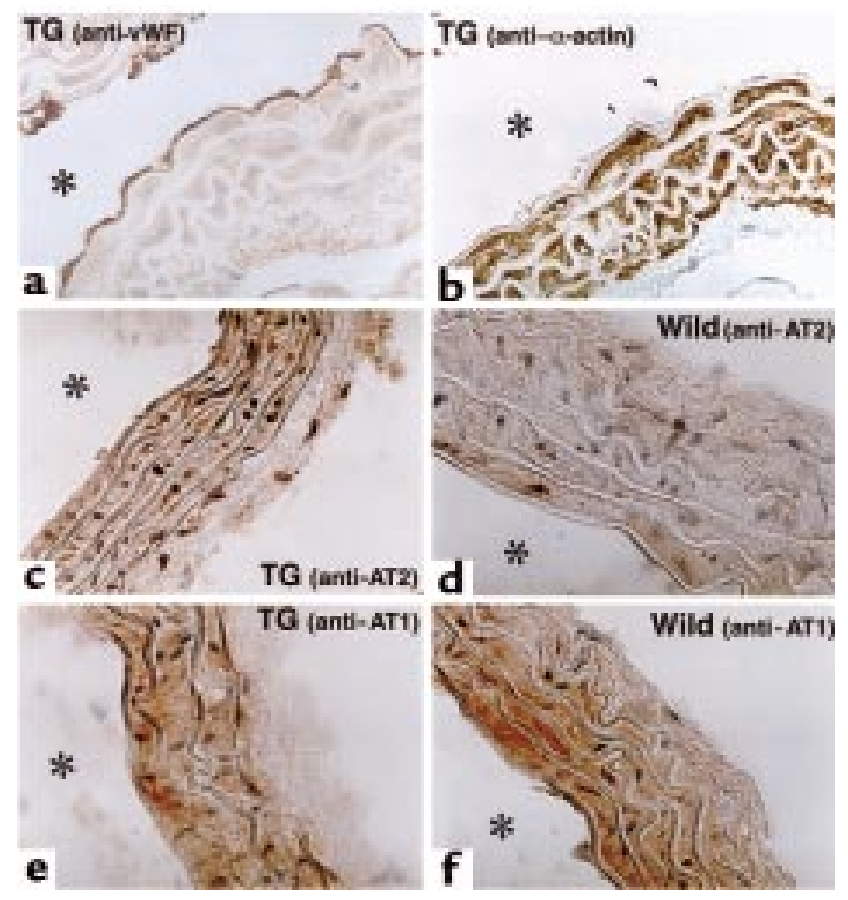

Figure 2

Immunohistochemical localization of AT2 and AT1 in the medial layer of the aorta. The immunostaining, using antibodies for von Willebrand factor (VWF) (a) and VSM-specific $\alpha$-actin (b), indicates the localization of the endothelium and medial layer in the aorta, respectively. Positive immunostaining for AT2 was highly localized in the medial layer of the aorta from AT2-TG mice (c), whereas in the wild-type mice, no significant AT2 signals were observed in the aorta (d). Immunochemical signals for AT1 were detected in the medial layers of the aortas from wild-type and AT2-TG mice to a similar extent (e and $\mathbf{f})$. Positive staining was viewed with avidin-biotin immunoperoxidase reaction using diaminobenzidine. Asterisks indicate the lumen of the aorta.

quinoline $(1 \mathrm{mg} / \mathrm{mL})$, soybean trypsin inhibitor (100 $\mu \mathrm{g} / \mathrm{mL})$, EDTA $(30 \mathrm{mmol} / \mathrm{L})$, captopril $(10 \mu \mathrm{g} / \mathrm{mL})$, and the NEP inhibitor phosphoramidon $(1 \mu \mathrm{mol} / \mathrm{L})$. The homogenate was centrifuged at 2,000 $\mathrm{g}$ for 10 minutes, and supernatants were used for the experiment. The tissue homogenate $(0.5 \mathrm{~mL})$ was incubated with bovine kininogen (2,000 ng; Seikagaku Kogyo, Tokyo, Japan) for 30 minutes at $37^{\circ} \mathrm{C}$, and then ethanol $(4 \mathrm{~mL})$ was added. After 5 minutes, the reaction mixture was centrifuged $(1,300 \mathrm{~g})$ for 10 minutes at $4^{\circ} \mathrm{C}$, the supernatant was separated out, and the pellet was washed with $80 \%$ ethanol and centrifuged again. Both supernatants were pooled and dried under nitrogen. Kinins generated during the incubation were measured by RIA as reported previously (31); the lower limit of sensitivity is $1.4 \mathrm{pg}$ per sample, and intra-assay $(n=10)$ and inter-assay $(n=5)$ coefficients of variations were $7.7 \%$ and $7.4 \%$, respectively. Kininogenase activity was expressed as the amount of kinins generated per milligram of protein per minute of incubation with kininogen (32).

Measurement of intracellular $\mathrm{pH}$. The fluorescent $\mathrm{pH}$-sensitive dye 2',7'-bis(carboxyethyl)-5(6)-carboxyfluorescein (BCECF/AM) was used to monitor changes in cytosolic 

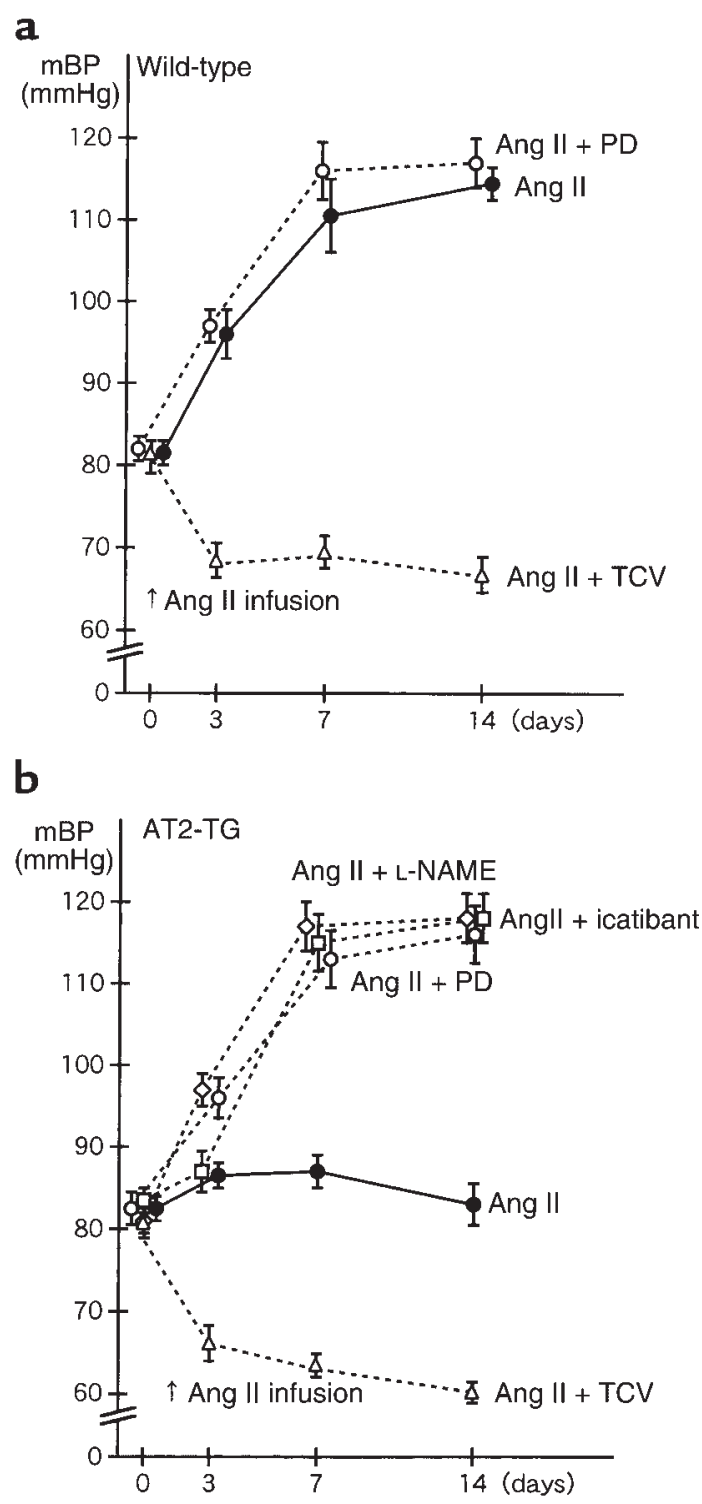

Figure 3

Changes in BP after Ang II infusion. The mBP was measured by the tail-cuff method as described in Methods. Ang II (0.7 mg/kg per day; $n=12)$ was chronically infused using an osmotic pump. Icatibant (70 $\mu \mathrm{g} / \mathrm{kg}$ per day; $n=10)$ and PD123319 (PD; $30 \mathrm{mg} / \mathrm{kg}$ per day; $n=$ 10) were coinfused with Ang II using an osmotic pump. TCV116 (TCV; $10 \mathrm{mg} / \mathrm{kg}$ per day; $n=10$ ) was given orally, and L-NAME (1 $\mathrm{mg} / \mathrm{mL}$ ) was given in drinking water.

$\mathrm{pH}$ as described previously $(33,34)$. The cells were rinsed and loaded with $2 \mu \mathrm{mol} / \mathrm{L}$ BCECF/AM (Wako Pure Chemicals Industries, Tokyo, Japan) for 60 minutes at $37^{\circ} \mathrm{C}$. BCECF was dissolved in physiological saline solution (PSS) containing (in mmol/L) $140 \mathrm{NaCl}, 4.6 \mathrm{KCl}, 1$ $\mathrm{MgCl}_{2}, 2 \mathrm{Ca}_{2}, 10$ glucose, and 10 HEPES (pH 7.4). BCECF/AM was dissolved in PSS. The complete intracellular hydrolysis of BCECF/AM to BCECF was judged according to changes in excitation and emission spectra. The fluorescence was monitored at $530 \mathrm{~nm}$, with excitation wavelengths of 450 and $500 \mathrm{~nm}$ in the ratio mode. After measurement of the basal intracellular $\mathrm{pH}\left(\mathrm{pH}_{\mathrm{i}}\right)$ level, the control medium was changed to media with varying extracellular $\mathrm{pH}$. Because autofluorescence of unloaded cells accounted for less than $1 \%$ of the total fluorescence of BCECF-loaded cells, autofluorescence did not affect the $\mathrm{pH}_{\mathrm{i}}$ calculations. The fluorescence signal was calibrated at several $\mathrm{pH}$ values (6.6, 7.0, and 7.4) in $\mathrm{KCl}$ solution containing (in mmol/L) $140 \mathrm{KCl}, 4.6$ $\mathrm{NaCl}, 1 \mathrm{MgCl}_{2}, 2 \mathrm{CaCl}_{2}, 10$ glucose, and 10 HEPES containing the $\mathrm{K}^{+} / \mathrm{H}^{+}$ionophore nigericin $(10 \mu \mathrm{g} / \mathrm{mL})$.

Cell culture. Aortic VSM cells were prepared from thoracic aorta by the explant method. The inner surfaces of isolated aorta were scraped to remove endothelial cells, minced into 1-mm pieces, and cultured in DMEM containing $10 \%$ FCS. After $2-3$ weeks, the cells migrating from the explants were removed by trypsinization and subcultured (passage 1). The identity of VSM cells was confirmed based on their typical morphological characteristic (spindle shape, hill-and-valley patterns) and immunostaining with an anti- $\alpha$-smooth muscle actin (1A4; Sigma Chemical Co., St. Louis, Missouri, USA). For the experiments, $\sim 80 \%$ confluent VSM cells (passage 3 ) were made quiescent by incubation with serum-free DMEM for 12 hours.

Western blotting. Western blotting was performed as previously reported $(35,36)$. Briefly, the aorta was isolated and homogenized in high-salt buffer containing (in mmol/L) $600 \mathrm{NaCl}, 40$ MOPS, 5 EGTA, 5 EDTA, 1 DTT, and $1 \mu \mathrm{g} / \mathrm{mL}$ leupeptin, $1 \mu \mathrm{g} / \mathrm{mL}$ aprotinin, and $50 \mathrm{mmol} / \mathrm{L}$ PMSF. The supernatant was separated by SDS-PAGE and transferred onto nitrocellulose membranes. Aliquots of $20 \mu \mathrm{g}$ of protein were loaded per lane and probed with one of the following antibodies: antihuman $\alpha$-smooth muscle (clone 1A4; Sigma Chemical Co., St. Louis, Missouri, USA), anti-human calponin (clone hCP; Sigma), and anti-caldesmon (clone hHCD; Sigma). The signals were detected by enhanced chemiluminescence (ECL; Amersham). Caldesmon is present as high-molecular-weight $(120-150 \mathrm{kDa})$ and lowmolecular-weight (71-80 kDa) species, and we focused on the high-molecular-weight caldesmon (hCD).

Immunohistochemistry. Immunohistochemistry was performed in frozen sections as described previously, with some modifications (36). The frozen aortas were cut at $6 \mu \mathrm{m}$ and stored at $-80^{\circ} \mathrm{C}$. The tissue was fixed with $2 \%$ paraformaldehyde. The endogenous peroxidase and nonspecific binding sites were blocked with $1 \%$ $\mathrm{H}_{2} \mathrm{O}_{2}, 7.5 \%$ normal goat serum, and $1 \%$ nonfat dry milk. Samples were incubated overnight at $4{ }^{\circ} \mathrm{C}$ with the following antisera: polyclonal anti-rat AT1 (Chemicon International, Temecula, California, USA), polyclonal anti-rat AT2 (kindly provided by A.S. Greene, University of Wisconsin ), anti-human von Willebrand factor (Sigma), and anti-rat $\alpha$-smooth muscle actin (Sigma). Staining was viewed with the avidin-biotin immunoperoxidase reaction (VECTASTAIN ABC Kit; Vector Laboratories, Burlingame, California, USA) using diaminobenzidine (Fast DAB tablets; Sigma).

Reagents and statistical methods. All reagents were purchased from Sigma Chemical Co., unless otherwise indi- 
a

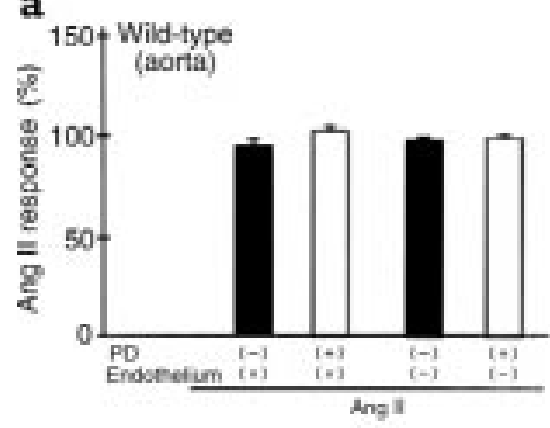

$c$

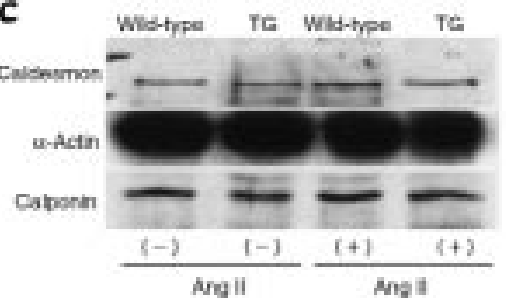

b

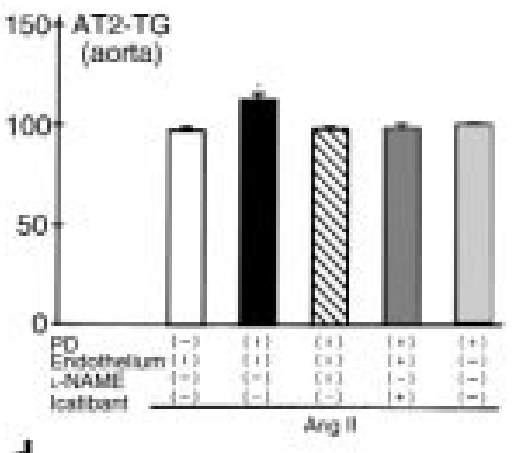

d

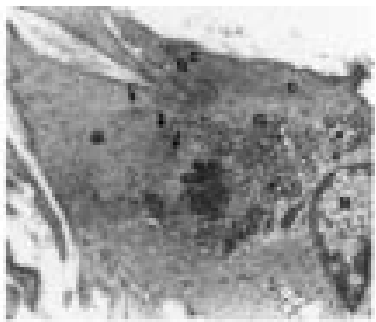

\section{Figure 4}

Ang II-induced constrictive response of the aorta ( $\mathbf{a}$ and $\mathbf{b}$ ), expression profile of vascular constriction-related proteins (c), and electron micrography of the aorta of AT2-TG mice (d). ( $\mathbf{a}$ and $\mathbf{b}$ ) Aortic strips were placed on a myograph under resting tension and equilibrated in bathing medium continuously bubbled with $\mathrm{O}_{2} / \mathrm{CO}_{2}(95: 5)$. The contractile response to $50 \mathrm{mmol} / \mathrm{L}$ Ang II was examined 3 times, and the contractile response after the third Ang II treatment was regarded as the control response for Ang II (100\%). Subsequently, the medium was washed out twice with fresh Tyrode's solution, and the vascular response to Ang II ( $50 \mathrm{nmol} / \mathrm{L} ; n=8)$ was recorded in the presence or absence of PD123319 (100 nmol/L; $n=8)$, L-NAME ( $1 \mu \mathrm{mol} / \mathrm{L} ; n=8)$, or icatibant $(100 \mathrm{nmol} / \mathrm{L} ; n=8)$. Removal of endothelium was performed by gently rubbing the intimal surface with a cotton pellet, and was verified by abolishment of the relaxation caused by $1 \mu$ mol/L acetylcholine. The results are expressed as means \pm SE. ${ }^{*} P<0.001$ vs. the control level. (c) Aortic homogenates (20 $\mu g$ protein) were analyzed by Western blotting using anti-caldesmon (high molecular weight), anti- $\alpha$-actin, and anti-calponin antibodies. Representative data of 3 separate experiments are shown. (d) Electron micrograph of a longitudinal section of smooth muscle fibers (VSM cells) in the aorta from AT2-TG mice. Part of the centrally located nucleus ( $N$ ) is included at the right. Mitochondria (M), a Golgi apparatus (G), and ribosomes (R) are particularly abundant in the conical perinuclear region. Caveolae $(C)$ are seen in plasma membranous regions. The remainder of the fiber is occupied by thin filaments (myofilament) (asterisk) and by dense bodies (arrows), into which the filaments appear to insert.

cated. Losartan was kindly provided by DuPont Merck Pharmaceutical (Wilmington, Delaware, USA). TCV116 and CV11974 were kindly provided by Takeda Chemical Industries (Osaka, Japan). PD123319 was provided by Warner-Lambert Co./Parke-Davis Pharmaceuticals (Ann Arbor, Michigan, USA). The results are expressed as means \pm SE. ANOVA and Dunnett's multiple comparison test or Student's $t$ test were used for multigroup comparisons, with $P<0.05$ considered significant.

\section{Results}

Expression of AT2 in aorta and VSM cells from VSM AT2-TG mice. The transgene construct contained the mouse VSM $\alpha$-actin promoter ligated to the coding sequence of mouse AT2. This promoter effects a pattern of transgene expression similar to that of endogenous VSM-specific $\alpha$-actin, which is the dominant $\alpha$-actin isoform in vascular tissue. Five founders containing the AT2 transgene were identified by PCR of genomic DNA. Neonatal mortality in these TG mice did not differ from that in non-TG controls. These animals had similar heart-tobody weight ratios relative to their control littermates (designated as wild-type), and there was no evidence of obvious morphological changes of the aorta.
Transgene expression assessed by ligand-binding assay revealed that AT2 was overexpressed in the aorta from 5 different TG lines, and the proportion of aortic AT2 relative to AT1 was 39\% in TG901 mice (Figure 1a). The expression of aortic AT2 was most abundant in TG901 mice among these 5 TG lines. Subsequent experiments were performed using this line. Smaller amounts of AT2 were detected in the aorta of wild-type mice ( $\sim 5 \mathrm{fmol} / \mathrm{mg}$ protein), and there were no significant differences in aortic AT1 numbers between TG and wild-type animals (Figure 1a). The $K_{\mathrm{d}}$ values (nmol/L) of AT2 in the aorta of TG and wild-type mice were $0.31 \pm 0.01$ and $0.33 \pm 0.01$, respectively, when saturation binding experiments were performed with AT2-selective ligand $\left[{ }^{125} \mathrm{I}\right] \mathrm{CGP} 42112 \mathrm{~A}$, in good agreement with the native binding affinity of AT2 $(37,38)$. The aortic AT2 densities were high (33-39\% vs. AT1 densities) in all TG lines and, therefore, could not be attributed to the site of genomic integration. Although we measured AT1 and AT2 densities in the aorta after removal of endothelium, there were no significant changes in the levels of receptor expression (Figure 1a). We also determined the AT2 densities in VSM cells isolated from the aorta using the explant method. Prima- 

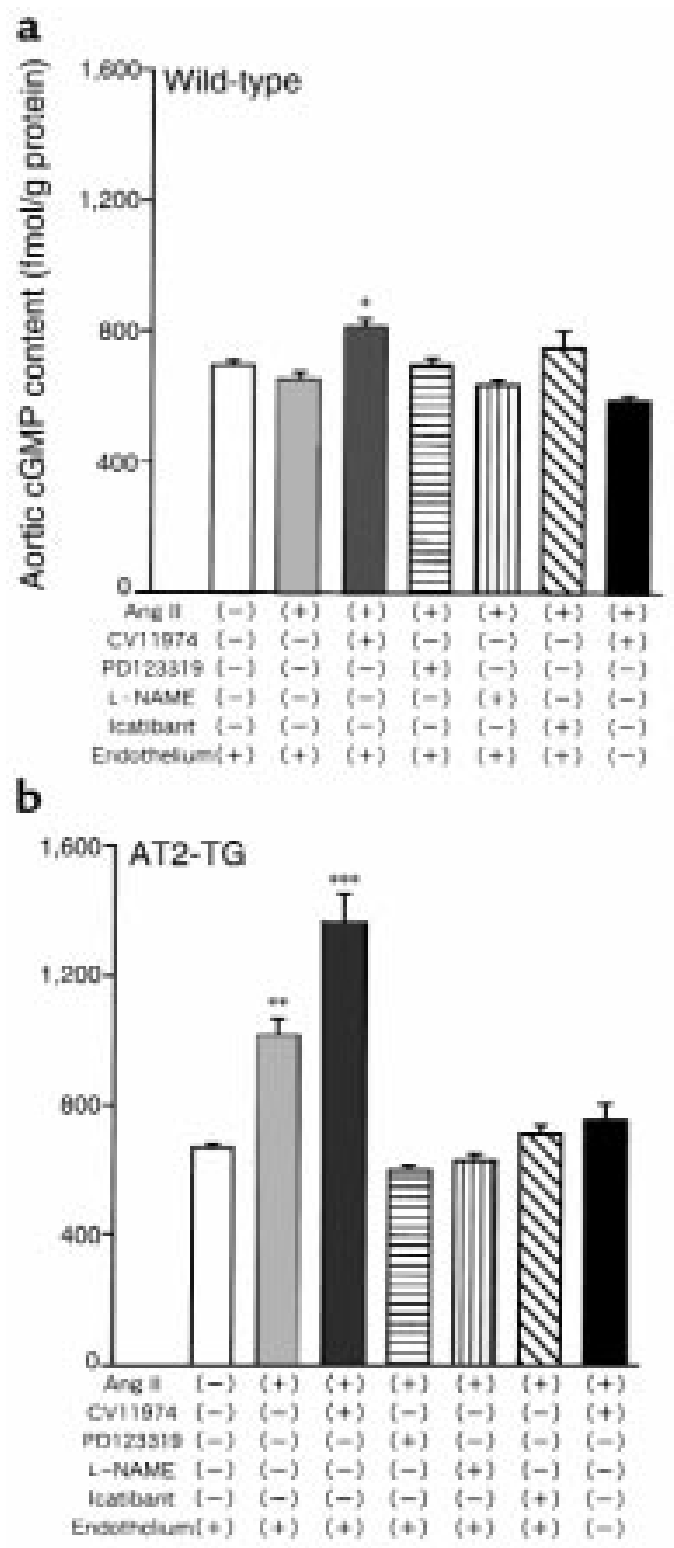

Figure 5

AT2-mediated increase of aortic cGMP content in a BK2 receptor/NO-dependent manner. Isolated aortas were placed in PSS and exposed to Ang II (100 nmol/L) for 10 minutes. CV11974 $(1 \mu \mathrm{mol} / \mathrm{L}$; $n=10), \operatorname{PD} 123319(1 \mu \mathrm{mol} / \mathrm{L} ; n=10)$, L-NAME $(1 \mu \mathrm{mol} / \mathrm{L} ; n=10)$, or icatibant $(1 \mu \mathrm{mol} / \mathrm{L} ; n=10)$ was added 15 minutes before addition of Ang II. The treated aortas were homogenized, and aortic cGMP content (femtomoles per gram of protein) was measured and compared with content in the control (no treatment; $n=10$ ) and Ang II-alone groups $(n=10)$. Removal of endothelium was performed by gently rubbing the intimal surface with a cotton pellet. ${ }^{*} P<0.05$, ${ }^{*} P<0.01,{ }^{*} * P<0.01$ vs. control.

ry cultures of VSM cells from AT2-TG mice expressed AT2 abundantly, and the proportion of AT2 to AT1 was $31 \%$ in passage 2 VSM cells, whereas no AT2 expression was detectable in wild-type cells (Figure 1b). Because we found that both AT1 and AT2 densities decreased markedly after passage 4 (Figure 1b), we used VSM cells at passage 3 for the subsequent experiments.
To further confirm VSM-specific overexpression of AT2, we performed immunohistochemical staining using specific antibodies. The immunostaining, using antibodies for von Willebrand factor (Figure $2 \mathrm{a}$ ) and VSM-specific $\alpha$-actin (Figure $2 \mathrm{~b}$ ), indicates the localization of endothelium and medial layer in the aorta. Positive immunostaining for AT2 is highly localized in the medial layer of the aorta from AT2-TG mice (Figure $2 \mathrm{c}$ ), whereas in the wild-type mice, no significant AT2 signals are observed in the aorta (Figure 2d). Immunochemical signals for AT1 are detected in the medial layers of aortas from wild-type and AT2-TG mice to a similar extent (Figure 2, e and f). Preimmune and preadsorption controls were negative for anti-AT2 and anti-AT1 antibodies (data not shown).

VSM-specific overexpression of AT2 gene abolished the Ang $I I-$ mediated pressor effect. Changes in $\mathrm{BP}$ and heart rate (HR) in response to chronic infusion of a low dose of Ang II $(0.7 \mathrm{mg} / \mathrm{kg}$ per day) were measured in conscious mice. Basal BP levels did not differ between AT2-TG and wildtype mice. Mean $\mathrm{BP}(\mathrm{mBP})$ levels in wild-type mice were significantly increased to $\sim 14 \mathrm{mmHg}(P<0.05), \sim 29$ $\mathrm{mmHg}(P<0.001)$, and $\sim 33 \mathrm{mmHg}(P<0.0001)$ at 3,7 , and 14 days after Ang II infusion, respectively. This elevation was inhibited by TCV116 $(10 \mathrm{mg} / \mathrm{kg}$ per day orally) but not PD123319 $(30 \mathrm{mg} / \mathrm{kg}$ per day by osmotic pump) (Figure 3a). Interestingly, BP elevation after Ang II infusion was markedly attenuated in AT2-TG mice, whereas simultaneous treatment with PD123319, NO synthase inhibitor L-NAME $(1 \mathrm{mg} / \mathrm{kg}$ per day orally), and BK2 receptor antagonist icatibant $(70 \mu \mathrm{g} / \mathrm{kg}$ per day by osmotic pump) elevated BP levels to an extent similar to those observed in wild-type controls (Figure 3b). L-NAME or icatibant alone slightly elevated the $\mathrm{mBP}$ level (LNAME: $11 \pm 1.2$; icatibant: $8 \pm 0.7 \mathrm{mmHg}$ after 14-day treatment; $n=8$ ) in AT2-TG mice. Basal HR did not differ between AT2-TG and wild-type mice, and chronic Ang II infusion did not show any significant effect on HR (data not shown). The mBP levels in wild-type and AT2TG mice were decreased by $16.3 \%$ and $26.5 \%$ from baseline values after a 14-day treatment with Ang II and TCV116 (AT2 stimulation), respectively, and the magnitude of BP depression was significantly $(P<0.05)$ greater in AT2-TG mice than in wild-type mice (Figure 3). These findings suggested that targeted overexpression of AT2 in VSM cells antagonizes the AT1-mediated pressor effect through a bradykinin/NO-dependent mechanism, and that selective AT2 stimulation causes a depressor effect. AT2 inbibits Ang II-mediated vasoconstriction action through endothelium-dependent vasodilation. To determine whether Ang II-mediated vascular responses are altered in AT2TG mice, we isolated the aorta from AT2-TG mice and tested vascular constrictive responses to Ang II. The Ang II-mediated constriction was recorded 3 times, and the third response was regarded as the control constriction to Ang II. The vasoconstrictive response to the fourth Ang II treatment was tested in the presence or absence of PD123319, which was shown as a ratio relative to the third Ang II-induced constriction (100\%, control). In 
wild-type mice, neither pretreatment with PD123319 nor removal of endothelium significantly affected the Ang II-induced vasoconstrictive response (Figure 4a). In AT2-TG mice Ang II-mediated vasoconstriction was enhanced by $19.8 \%$ ( $P<0.001$ vs. control) by PD123319 pretreatment. Removal of endothelium and pretreatment with icatibant or L-NAME abolished this AT2mediated vascular effect (Figure 4b), suggesting that AT2 antagonizes the AT1-mediated vasoconstrictive action through a bradykinin/NO-mediated pathway in an endothelium-dependent manner.

We next tested whether targeted overexpression of AT2 in VSM cells alters the norepinephrine-induced vascular response or affects the expression of endogenous proteins involved in vascular constriction, such as VSM $\alpha$ actin, calponin, and caldesmon. Western blotting analyses indicated that VSM-specific $\alpha$-actin and actin-related regulatory proteins calponin and caldesmon were expressed at comparable levels in AT2-TG and wild-type mice (Figure 4c). The norepinephrine-induced vasoconstrictive response of isolated aorta was also similar between AT2-TG and wild-type mice (data not shown). Electron micrography analysis of aorta microstructure revealed that overexpression of AT2 does not affect the microstructure of myofilaments (thin filaments), a Golgi apparatus, dense body, ribosome, or caveolae in VSM cells compared with those in wild-type mice (only data of AT2-TG mice shown in Figure 4d).

Ang II-mediated aortic cGMP production is increased in the aorta of AT2-TG mice through a bradykinin/NO-dependent mechanism. Because the AT2-mediated vasodilatory effect was inhibited by L-NAME (Figure 4b), we isolated the aorta from AT2-TG mice and examined the effect of AT2 on aortic cGMP synthesis. Basal cGMP content in the isolated aorta did not significantly differ between AT2TG and wild-type mice. Ang II (100 nmol/L) alone did not induce a significant increase in aortic cGMP level of wild-type mice, whereas addition of Ang II in the presence of CV11974 (active form of TCV116) resulted in a $26 \%$ increase $(P<0.05$ vs. control) in aortic cGMP level (Figure 5a). In AT2-TG mice, Ang II alone resulted in a $53 \%$ increase $(P<0.01$ vs. control) in aortic cGMP level, and combination of Ang II and CV11974 induced a further increase (105\% vs. control; $P<0.001$ ) (Figure 5b). Pretreatment with PD123319, L-NAME, and icatibant blocked the AT2-induced increase in aortic cGMP production in both wild-type and AT2-TG mice (Figure 5, a and b). Interestingly, removal of endothelium also completely abolished this AT2-mediated aortic cGMP production in both wild-type and AT2-TG mice (Figure 5, a and $b$ ). These findings suggested that targeted overexpression of AT2 in VSM cells stimulates endotheliumdependent cGMP synthesis through the bradykinin/NO pathway, and that AT2 present in the aorta of wild-type mice has the ability to stimulate aortic cGMP synthesis by the same mechanism as in AT2-TG mice.

Aortic kininogenase activity is increased by stimulation of AT2. We next studied whether AT2 activates the kininkallikrein system in the isolated aorta. Previous studies
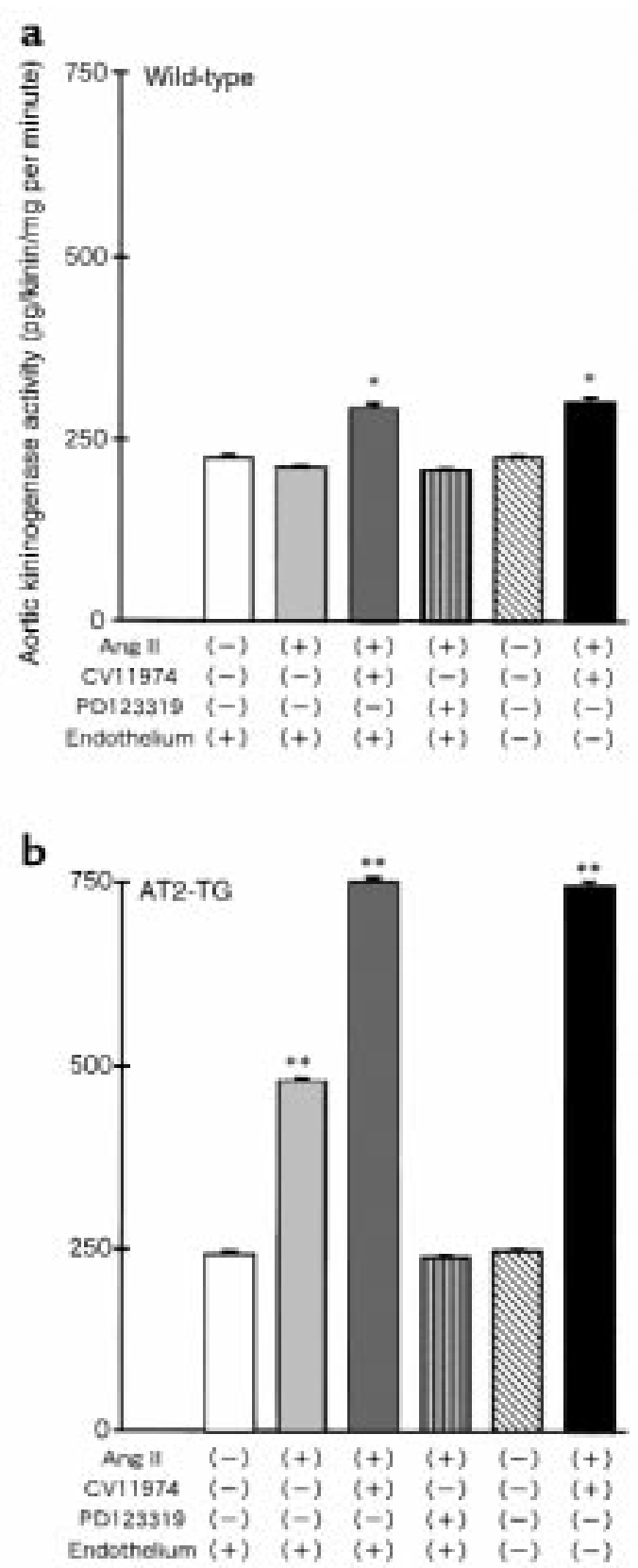

Figure 6

AT2-mediated increase of aortic kininogenase activity. Isolated aortas were treated by the same protocol as described in Figure 6. Aortic kininogenase activities (picograms per milligram of protein per minute) in tissue homogenates were quantified by measuring the kinins generated from added kininogen as described in Methods. $n=$ 8 for each experiment. ${ }^{*} P<0.05,{ }^{*} P<0.01$ vs. control.

indicated that rat aorta $(32,39)$ and rat aortic VSM cells (32) synthesize and secrete kininogen, kininogenases, and kininases into the culture medium. We found that the amount of bradykinin released from isolated aorta or aortic VSM cells into the incubation medium was too low to be detected by the RIA, even in the presence of kininase inhibitors such as captopril and NEP inhibitor phosphoramidon. Therefore, as performed in previous studies $(32,39)$, we assayed the kininogenase 
a
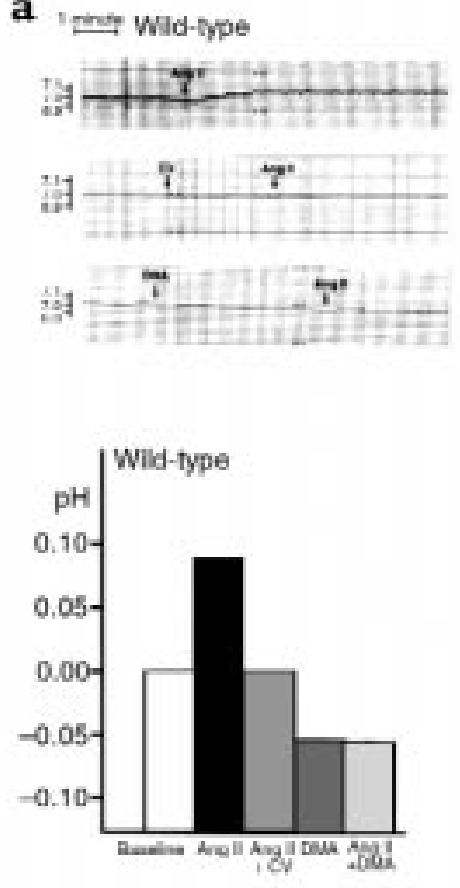

b
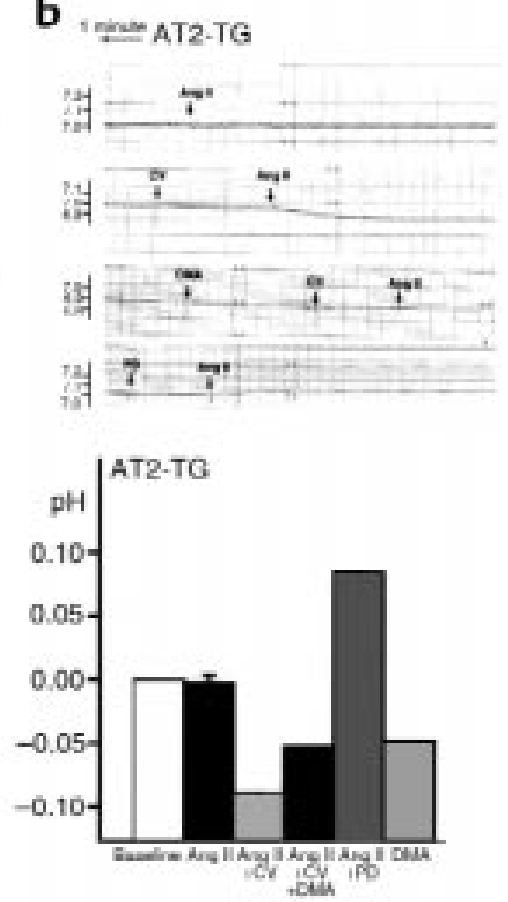

Figure 7

AT2-mediated intracellular acidosis through inhibition of the amiloride-sensitive $\mathrm{Na}^{+} / \mathrm{H}^{+}$exchanger. The $\mathrm{pH}$-sensitive dye BCECF was used to monitor changes in cytosolic $\mathrm{pH}_{\mathrm{i}}$ as described in Methods. The aortic VSM cells from wild-type (a) and AT2-TG (b) mice were rinsed and loaded with $2 \mu \mathrm{mol} / \mathrm{L} \mathrm{BCECF}$ for 60 minutes at $37^{\circ} \mathrm{C}$. Fluorescence was monitored at $530 \mathrm{~nm}$, with excitation wavelengths of 450 and $500 \mathrm{~nm}$ in the ratio mode. After measurement of the basal $\mathrm{pH}_{\mathrm{i}}$ level, the control medium was changed to that with varying extracellular $\mathrm{pH}$. The fluorescence signal was calibrated at several $\mathrm{pH}$ values $(6.6,7.0$, and 7.4$)$ in $\mathrm{KCl}$ solution containing the $\mathrm{K}^{+} / \mathrm{H}^{+}$ionophore nigericin. CV11974 (CV; $0.5 \mu \mathrm{mol} / \mathrm{L})$, PD123319 (PD; $0.5 \mu \mathrm{mol} / \mathrm{L})$, and DMA (30 $\mu \mathrm{mol} / \mathrm{L})$ were preadded; then the cells were exposed to Ang II $(100 \mathrm{nmol} / \mathrm{L})$. Similar results were obtained from 6 separate experiments, and representative data are shown (top panels). Changes of $\mathrm{pH}_{\mathrm{i}}$ from the baseline values 10 minutes after addition of Ang II were calculated, and are shown relative to the baseline value (bottom panels; $n=6$ ). ${ }^{*} P<0.05$, ${ }^{*} P<0.01$ vs. the baseline value. (kinin-forming) activity in the isolated aorta homogenate using exogenous bovine kininogen as a substrate to generate bradykinin. Kininogenase activities obtained from mouse urine or aortic homogenates were linearly plotted as a function of incubation time (during 1 hour; data not shown), indicating that mouse kininogenases act on bovine kininogen to generate bradykinin. Kininogenase activity in blood-free aortic homogenate of wild-type mice was $223 \pm 4.8 \mathrm{pg}$ kinin/mg protein per minute $(n=12)$ (Figure 6a). Aorta denuded of endothelium had the same amount of kininogenase activity $(225 \pm 3.4 \mathrm{pg} / \mathrm{mg}$ per minute $(n=$ 12 ) as intact aorta. Therefore, subsequent experiments were performed using tissue homogenates from the aorta with endothelium.

Ang II treatment alone did not affect aortic kininogenase activity in the wild-type mice, whereas a combination of Ang II and CV11974 induced a slight but significant increase $(29 \% ; P<0.05)$ (Figure 6a). Interestingly, in the aorta of AT2-TG mice, Ang II stimulated the kininogenase activity by as much as $97 \%(P<0.001)$, and pretreatment with CV11974 further increased its activity by $57 \%$ (Figure $6 \mathrm{~b}$ ). This kininogenase activity was entirely inhibited by addition of $10 \mu \mathrm{g}$ of aprotinin during incubation (data not shown). Pretreatment with PD123319 completely abolished this AT2-mediated increase in kininogenase activity, whereas removal of endothelium did not affect its induction in wild-type or AT2-TG mice (Figure 6, $a$ and $b$ ). These findings suggested that targeted overexpression of AT2 in VSM cells markedly stimulates aortic aprotinin-sensitive kininogenase activity in an endothelium-independent manner, and that AT2 present in the aorta of wild-type mice has the ability to slightly stimulate aortic kininogenase activity by the same mechanism as in AT2-TG mice.
Intracellular acidic changes induced by AT2 stimulation enhance kininogenase activity in aortic VSM cells. Stimulation of AT1 was reported to cause intracellular alkalization in rat aortic VSM cells through activation of the amiloride-sensitive $\mathrm{Na}^{+} / \mathrm{H}^{+}$exchanger (34); also, the aorta was shown to contain acid-optimum kininogenases $(40,41)$. Therefore, we examined whether AT2 modifies $\mathrm{pH}_{\mathrm{i}}$ level to stimulate the kininogenase activity in aortic VSM cells. Addition of Ang II to aortic VSM cells from wild-type mice resulted in a gradual increase in $\mathrm{pH}_{\mathrm{i}}$ level (+0.092 from baseline after 10 minutes); this effect was completely inhibited by the AT1 antagonist CV11974 (Figure 7a). Inhibition of amiloride-sensitive $\mathrm{Na}^{+} / \mathrm{H}^{+}$exchanger activity by amiloride derivative 5-( $N, N$-dimethyl)-amiloride (DMA) induced intracellular acidosis (-0.053 from baseline after 10 minutes) in VSM cells from wild-type mice, and pretreatment with DMA inhibited Ang II-mediated increase in $\mathrm{pH}_{\mathrm{i}}$ level (Figure 7a). Pretreatment with PD123319 did not affect the Ang II-induced change in $\mathrm{pH}_{\mathrm{i}}$ level (data not shown), indicating that AT1 causes intracellular alkalization through activation of the amiloride-sensitive $\mathrm{Na}^{+} / \mathrm{H}^{+}$exchanger. The lack of an effect of AT2 may reflect downregulation of AT2 in cultured aortic VSM cells from wild-type mice, as shown in Figure $1 \mathrm{~b}$.

Interestingly, in aortic VSM cells from AT2-TG mice, addition of Ang II alone did not affect the $\mathrm{pH}_{\mathrm{i}}$ level. Addition of Ang II in the presence of CV11974 (AT2 stimulation) induced a marked decrease in the $\mathrm{pH}_{\mathrm{i}}$ level (-0.091 from baseline after 10 minutes); this AT2-mediated acidic change was abolished by DMA pretreatment (Figure 7b). Treatment with DMA alone also caused a gradual decrease in the $\mathrm{pH}_{\mathrm{i}}$ level $(-0.048$ after 10 minutes) (Figure 7, a and b). Pretreatment with PD123319 (AT1 stimulation) induced intracellular alkalization 
during exposure to Ang II ( +0.091 from baseline after 10 minutes). These findings demonstrated that AT2 induces intracellular acidosis through inhibition of amiloride-sensitive $\mathrm{Na}^{+} / \mathrm{H}^{+}$exchanger activity.

We next studied the relationship between kininogenase activity and AT2-mediated acidic changes. Basal kininogenase activity in aortic VSM cells from AT2-TG mice was $372 \pm 8.8 \mathrm{ng} / \mathrm{mg}$ protein per minute (control). Ang II stimulated the kininogenase activity by $32 \%$ (10 minutes after addition; $P<0.01$ vs. control), and AT2 stimulation by Ang II and CV11974 further increased its activity by $84 \%$ ( $P<0.001$ vs. control). AT1 stimulation by Ang II and PD123319 did not affect the kininogenase activity. Treatment with DMA alone stimulated the kininogenase activity to an extent comparable with that in AT2-stimulated cells. Because both AT2 stimulation and DMA cause a similar level of intracellular acidosis through inhibition of $\mathrm{Na}^{+} / \mathrm{H}^{+}$exchanger activity, it is likely that intracellular acidic changes play an important role in enhancing the kininogenase activity in aortic VSM cells.

\section{Discussion}

In this study, targeted overexpression of AT2 in aortic VSM cells was shown to antagonize AT1-mediated vasoconstrictive and pressor effects through an endotheliumdependent mechanism. This AT2-mediated vasodilatory action was caused by the paracrine effect of bradykinin, leading to activation of the endothelial BK2-mediated $\mathrm{NO} / \mathrm{cGMP}$ system. Aortic kininogenase activity is stimulated by AT2, indicating that AT2 is able to regulate the activity of vascular kinin-kallikrein system. The involvement of endothelium in generation of bradykinin was unlikely, because removal of endothelium did not affect the AT2-mediated effect on aortic kininogenase activity. These findings suggested that bradykinin is liberated from VSM cells by AT2 stimulation, which, in turn, acts on the endothelial bradykinin receptor in a paracrine manner to cause endothelium-dependent vasodilation (Figure 8). Furthermore, we believe that this study also provided the first evidence that AT2 causes intracellular acidosis through inhibition of amiloride-sensitive $\mathrm{Na}^{+} / \mathrm{H}^{+}$ exchanger activity, resulting in enhancement of kininogenase activity in aortic VSM cells.

Although the depressor and vasodilatory actions of AT2 have not yet been clarified in detail, recent evidence has suggested that AT2 mediates functions opposing the pressor action of AT1. In mature rats, AT2 mediates the depressor phase of the biphasic BP response to Ang II (42), and chronic treatment with PD123319 enhances the Ang II-mediated pressor action (43). Similar results were found in isolated middle cerebral arteries, in which specific blockade of AT2 potentiated Ang II-induced VSM cell contraction (42). Furthermore, Ichiki et al. (9) and Hein et al. (10) established AT2 knockout mice and found that the Ang II-induced pressor effect was enhanced in these mice. Although several studies demonstrated that AT2 inhibits AT1-mediated mitogen signals by activating tyrosine phosphatase or serine/threonine phosphatase $(4,44)$, the mechanism by which vasodila-

\section{Angiotensin II

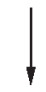 \\ AT2 receptor}

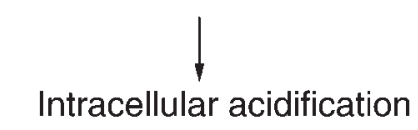

$\stackrel{\downarrow}{\text { Kininogenase activation }}$

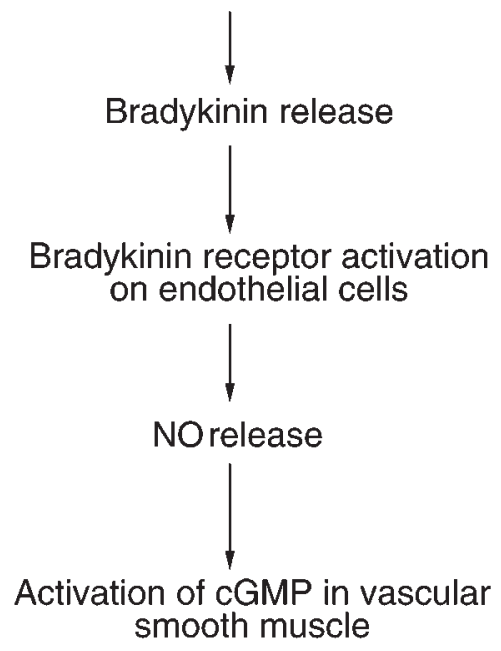

Figure 8

Proposed pathway responsible for AT2-mediated cGMP synthesis in VSM cells. AT2 stimulation in aortic VSM cells causes intracellular acidification, resulting in the production of bradykinin through activation of kininogenases that function on the endothelial BK2 receptor in a paracrine mechanism to cause vasodilation through activation of the NO/cGMP system.

tory and depressor actions of AT2 are induced remained poorly characterized. However, the involvement of the NO system in Ang II signaling has been suggested in studies using bovine endothelial cells (12), isolated rat carotid arteries (13), canine microvessels from coronary arteries (14), rat aortic strips (15), and rat kidney (21). Siragy and Carey (21) reported using a microdialysis technique in which AT2 stimulates renal production of cGMP in response to $\mathrm{Na}^{+}$depletion; this effect is mediated by NO production (22). AT2-mediated NO production is necessary for AT2-mediated pressure natriuresis and diuresis $(19,20)$. The involvement of the bradykinin system in AT2 signaling has been proposed in various studies in vivo. In a rat model of heart failure due to myocardial infarction (16), reduced cardiac function and cardiac fibrosis were improved by an AT2 antagonist and a bradykinin receptor antagonist. In stroke-prone spontaneously hypertensive rats (18), aortic cGMP production stimulated by Ang II infusion was inhibited by an AT2 antagonist and a bradykinin receptor antagonist. In the present study using targeted overexpression of AT2 in mice, we clearly demonstrated that AT2 increases the kininogenase activity in VSM cells and that resultant gen- 
eration of bradykinin causes endothelium-dependent vasodilatory and depressor effect through an NO/cGMP pathway. This bradykinin originated from VSM cells (but not endothelial cells) and functioned on its specific receptor, which is present in endothelial cells in a paracrine mechanism. Although we tested the direct action of exogenous bradykinin on the aorta denuded of endothelium, no significant changes were observed in vascular constrictive responses (data not shown). These findings suggested that VSM cells, which are known to express kininogenase and kininogen (45), have the ability to stimulate the synthesis and/or release of bradykinin under conditions in which vascular AT2 is selectively stimulated by application of AT1 antagonists or in which its expression is increased by vascular injury.

Expression of AT2 in the adult rat aorta (SpragueDawley rats) has been demonstrated by binding studies and quantitative autoradiography (6). The data indicated localization of AT2 throughout the aortic wall (including the medial layer), although the cellular localization of AT2 was not defined. Similar results were obtained in Wistar-Kyoto and spontaneously hypertensive rats (7). Endothelial cells derived from coronary arteries of spontaneously hypertensive rats express AT1 and AT2 in an 80:20 ratio (46). In rat aortic endothelial cells, AT1 is the major subtype and AT2 is detected only in proliferating cells cultured without growth factors (47). Whereas the presence of functional AT2 was demonstrated in endothelial cells from bovine aorta (12), other studies failed to detect AT2 in endothelial cells derived from bovine aorta (48) or porcine arteries (49). In the human kidney, we reported the localization of AT2 mRNA in the medial layer of interlobular arteries (50). In this study, the results of the ligand-binding assay (Figure 1) showed that small amounts of AT2 were present in the isolated aorta of wild-type mice, and that removal of endothelium did not affect its expression level. Nora et al. (8) developed an excellent anti-AT2 antibody suitable for immunohistochemistry, and showed that rat AT2 expression varies with vessel size and is more abundant in endothelial and VSM cells in microvessels than in large vessels (6). Using this anti-AT2 antibody (provided by Nora et al.), we found that the expression of AT2 is not characterized in the endothelium of the aorta from wild-type or AT2-TG mice (Figure 2). Although these lines of evidence suggest that VSM cells express AT2 mainly in large vessels and microvessels, demonstration of endothelial AT2 depends largely on the experimental conditions, species, and vessel size.

The way in which AT2 stimulates the kininogenase activity could not be fully determined based on the results of this study. Although a previous study reported that in rat kidney slices, high $\mathrm{K}^{+}$, arginine vasopressin, and oxytocin levels stimulate kininogenase activity (51), the mechanism by which the activity of kininogenase is regulated remains poorly defined. The present study demonstrated clearly that AT2 causes intracellular acidic changes through inhibition of amiloride-sensitive $\mathrm{Na}^{+} / \mathrm{H}^{+}$exchanger activity, and that intracellular acidic change itself stimulates the activities of kininogenases in aortic VSM cells. The kininogenase activities were completely inhibited by aprotinin, consistent with a previous observation using rat aortic VSM cells (32). The steady-state mRNA levels for true kallikrein (KLK1), assessed by RT-PCR (52) or kininogen content, were similar in aortic VSM cells from wild-type or AT2-TG mice, and its expression was not affected by AT2 stimulation (data not shown). Because vascular tissue is known to contain the acid-optimum kininogenases (40), intracellular acidosis could be a stimulus for the activity of acid-optimum kininogenases that cleave bradykinin from intracellularly stored kininogens. Alternatively, intracellular acidic changes might affect an endogenous inhibitor protein that binds specifically to active tissue kallikrein and inhibits its activity (41). Several protein kinases have been suggested to regulate $\mathrm{Na}^{+} / \mathrm{H}^{+}$exchanger activity, including $\mathrm{Ca}^{2+} /$ calmodulin-dependent kinases, cAMP-dependent kinases, and extracellular signal-regulated kinases (ERKs) (53). Takahashi et al. reported that a 90-kDa kinase (RSK) activated downstream of ERKs is a putative kinase for the $\mathrm{Na}^{+} / \mathrm{H}^{+}$exchanger, and that Ang II phosphorylates this RSK through AT1-mediated signaling (54). Considering that recent evidence established that AT2 inhibits the phosphorylation of ERKs activated by AT1 $(4,44)$, it is likely that AT2-mediated inhibition of $\mathrm{Na}^{+} / \mathrm{H}^{+}$exchanger activity is caused by a decrease in RSK activity due to inhibition of AT1-mediated ERK activation.

The findings of this study have important pharmacotherapeutic implications for the AT1 antagonists that have been used recently for treatment of patients with hypertension or cardiovascular diseases. Because AT2 is present in microvessels at high levels (6-8), and AT2 activation is increased in atherosclerosis lesions of the aorta (55) and neointima after vascular injury (56), the AT2mediated depressor effect of the bradykinin/NO system is expected to contribute to the management of $\mathrm{BP}$, coronary microcirculation, and vascular remodeling with AT1 antagonists. We believe we have shown that AT2 stimulation has a novel hemodynamic effect by inhibiting AT1mediated chronotropic actions without affecting cardiac contractility (24). These novel hemodynamic actions mediated by AT2, such as negative chronotropic effects or activation of the bradykinin/NO system, suggest that AT2 exerts a new type of cardiovascular protective effect and that this novel cardiovascular protective effect of AT2 should be confirmed in clinical studies.

\section{Acknowledgments}

This study was supported in part by research grants from the Ministry of Education, Science and Culture, Japan; the Study Group of Molecular Cardiology; the Naito Foundation; the Clinical Pharmacology Foundation; the Japan Medical Association; the Japan Smoking Foundation; and the Japan Heart Foundation. S. Murasawa is a Research Fellow of the Japan Society for the Promotion of Science. We thank H. Fujimura (Tanabe Seiyaku) for excellent electron micrography; A.S. Greene for providing 
anti-AT2 antibody; and M. Majima (Kitasato Medical College) and K. Ura (Sapporo Medical College) for the helpful comment about measurement of kininogenases.

1. Baker, K.M., Booz, G.W., and Dostal, D.E. 1992. Cardiac actions of angiotensin II: role of an intracardiac renin-angiotensin system. Annu. Rev. Physiol. 54:227-241.

2. Inagami, T., and Kitami, Y. 1994. Angiotensin II receptor: molecular cloning, functions and regulation. Hypertens. Res. 17:87-97.

3. Matsubara, H., and Inada, M. 1998. Molecular insights into angiotensin II type 1 and type 2 receptors: expression, signaling and physiological function and clinical application of its antagonists. Endocr. J. 45:137-150.

4. Matsubara, H. 1998. Pathophysiological roles of angiotensin II type2 receptor in cardiovascular and renal diseases. Circ. Res. 83:1182-1191.

5. Shibasaki, Y., et al. 1999. Differential kinetics of circulating angiotensin IV and II after treatment with angiotensin II type 1 receptor antagonist and their plasma levels in patients with chronic renal failure. Clin. Nephrol. 51:83-91.

6. Vinswanathan, M., Tsutsumi, K., Correa, F.M.A., and Saavedra, J.M. 1991. Changes in expression of angiotensin receptor subtypes in the rat aorta during development. Biochem. Biophys. Res. Commun. 179:1361-1367.

7. Song, Y., et al. 1995. Mapping of angiotensin II receptor subtypes in peripheral tissues of spontaneous hypertensive rats by in vitro autoradiography. Clin. Exp. Pharmacol. Physiol. 22(Suppl. 1):S17-S19.

8. Nora, E.H., Munzenmaier, D.H., Hansen-Smith, F.M., Lombard, J.H., and Greene, A.S. 1998. Localization of the ANG II type2 receptor in the microcirculation of skeletal muscle. Am. J. Physiol. 275:H1395-H1403.

9. Ichiki, T., et al. 1995. Effects on blood pressure and exploratory behavior of mice lacking angiotensin II type-2 receptor. Nature. 377:748-750.

10. Hein, L., Barsh, G.S., Pratt, R.E., Dzau, V.J., and Koblika, B.K. 1995. Behavioural and cardiovascular effects of disrupting the angiotensin II type-2 receptor gene in mice. Nature. 377:744-747.

11. Pitt, B., et al. 1997. Randomised trial of losartan versus captoril in patients over 65 with heart failure. Lancet. 349:747-752.

12. Wiemer, G., et al. 1993. The functional role of angiotensin II-subtype 2receptors in endothelial cells and isolated ischemic rat hearts. Pharm. Pharmacol. Lett. 3:24-27.

13. Boulanger, C.M., Caputo, L., and Levy, B.I. 1995. Endothelial AT1-mediated release of nitric oxide decreases angiotensin II contractions in rat carotid artery. Hypertension. 26:752-757.

14. Seyedi, N., Xu, X.B., Najiletti, A., and Hintze, T.H. 1995. Coronary kinin generation mediates nitric oxide release after angiotensin receptor stimulation. Hypertension. 26:164-170.

15. Munzenmaier, D.H., and Greene, A.S. 1994. Stimulation of soluble guanylate cyclase activity by angiotensin II is mediated by a non-AT1 receptor mechanism in rat aorta. FASEB J. 8:A367.(Abstr.)

16. Liu, Y.H., et al. 1997. Effects of angiotensin-converting enzyme inhibitors and angiotensin II type 1 receptor antagonists in rat with heart failure. Role of kinins and angiotensin II type 2 receptors. J. Clin. Invest. 99:1926-1935.

17. Bartunek, J., Weinberg, E.O., Tajima, M., Rohrbach, S., and Lorell, B.H. 1999. Angiotensin II type 2 receptor blockade amplifies the early signals of cardiac growth response to angiotensin II in hypertrophied hearts. Circulation. 99:22-25.

18. Gohlke, P., Pees, C., and Unger, T. 1998. AT2 receptor stimulation increases aortic cyclic GMP in SHRSP by a kinin-dependent mechanism. Hypertension. 31:349-355

19. Lo, M., Liu, K.L., Lantelme, P., and Sassard, J. 1995. Subtype 2 of angiotensin II receptors controls pressure-natriuresis in rats. J. Clin. Invest. 95:1394-1397.

20. Madrid, M.I., Garcia-Salom, M., Torenel, J., de Gasparo, M., and Fenoy, F.J. 1997. Effect of interactions between nitric oxide and angiotensin II on pressure diuresis and natriuresis. Am. J. Physiol. 273:R1676-R1682.

21. Siragy, H.M., and Carey, R.M. 1996. The subtype-2 (AT2) angiotensin receptor regulates renal cyclic guanosine $3^{\prime}, 5^{\prime}$-monophosphate and AT1 receptor-mediated prostaglandin E2 production in conscious rats. J. Clin. Invest. 97:1978-1982.

22. Siragy, H.M., and Carey, R.M. 1997. The subtype 2 (AT2) angiotensin receptor mediates renal production of nitric oxide in conscious rats. J. Clin. Invest. 100:264-269.

23. Kawada, N., et al. 1999. The role of intron 1 in smooth muscle-actin transcriptional regulation in activated mesangial cells in vivo. Kidey Int. 55:2338-2348.

24. Masaki, H., et al. 1998. Cardiac-specific overexpression of angiotensin AT2 receptor causes attenuated response to AT1 receptor-mediated pressor and chronotropic effects. J. Clin. Invest. 101:527-535.

25. Kijima, K., Matsubara, H., Komuro, I., Yazaki, Y., and Inada, M. 1996. Mechanical stretch induces enhanced expression of angiotensin II receptors in neonatal rat cardiac myocytes. Circ. Res. 79:887-897.

26. Tsutsumi, Y., et al. 1998. Angiotensin II type 2 receptor is up-regulated in human heart with interstitial fibrosis and cardiac fibroblasts are the major cell type for its expression. Circ. Res. 83:1035-1046.
27. Takai, S., et al. 1998. 12-hydroxy-eicosatetraenoic acid directly potentiates angiotensin II-induced vascular contraction. Eur. J. Pharmacol. 358:161-164. 28. Sugaya, T., et al. 1995. Angiotensin II type 1a receptor-deficient mice with hypotension and hyperreninemia. J. Biol. Chem. 270:18719-18722.

29. Carretero, O.S., Oza, N.B., Pionska, A., Ocholik, T., and Scicli, A.G. 1976. Measurement of urinary kallikrein activity by kinin radioimmunoassay. Biochem. Pharmacol. 25:2265-2270.

30. Nolly, H., Scicli, A.G., Scicli, G., and Carretero, O.S. 1985. Characterization of a kininogenase from rat vascular tissue resembling tissue kallikrein. Circ. Res. 56:816-821.

31. Shimamoto, K., et al. 1982. An improved method for the determination of human blood kinin levels by sensitive kinin radioimmunoassay. Endocrinol. Jpn. 29:487-494.

32. Oza, N.B., Schwartz, J.H., Goud, H.D., and Levinsky, N.G. 1990. Rat aortic smooth muscle cells in culture express kallikrein, kininogen and bradykinin activity. J. Clin. Invest. 85:597-600.

33. Ishikawa, S., Okada, K., and Saito, T. 1992. pH dependence of the action of arginine vasopressin in renal collecting tubule. Am. J. Physiol. 31:F784-F792.

34. Berk, B.C., et al. 1987. Angiotensin II-stimulated $\mathrm{Na}^{+} / \mathrm{H}^{+}$exchange in cultured vascular smooth muscle cells. J. Biol. Chem. 262:5057-5064.

35. Murasawa, S., et al. 1998. Angiotensin II type 1 receptor-induced extracellular signal-regulated protein kinase activation is mediated by $\mathrm{Ca}^{2+} /$ calmodulin-dependent transactivation of epidermal growth factor receptor. Circ. Res. 82:1338-1348.

36. Ozono, R, et al. 1997. Expression of the subtype 2 angiotensin (AT2) receptor protein in rat kidney. Hypertension. 30:1238-1246.

37. Mukoyama, M., et al. 1993. Expression cloning of type 2 angiotensin II receptor reveals a unique class of seven-transmembrane receptors. J. Biol. Chem. 268:24539-24542.

38. Ichiki, T., et al. 1995. Effects on blood pressure and exploratory behavior of mice lacking angiotensin II type-2 receptor. Nature. 377:748-750.

39. Nolly, H., Carretero, O.A., and Scicli, A.G. 1993. Kallikrein release by vascular tissue. 1993. Am. J. Physiol. 265:H1209-H1214.

40. Moshi, M.J., Zeitlin, I.J., Wainwright, C.L., and Parratt, J.R. 1992. Acid optimum kininogenases in canine myocardium and aorta. Cardiovasc. Res. 26:367-370.

41. Chao, J., et al. 1990. Tissue kallikrein-binding protein is a serpin. I. Purification, characterization, and distribution in normotensive and spontaneously hypertensive rats. J. Biol. Chem. 265:16394-16401.

42. Scheuer, D.A., and Perrone, M.H. 1993. Angiotensin type2 receptors mediate the depressor phase of biphasic pressure response to angiotensin II. Am. J. Physiol. 264:R917-R923.

43. Munzenmaier, D.H., and Greene, A.S. 1996. Opposing actions of angiotensin II on microvascular growth and arterial blood pressure. Hypertension. 27:760-765.

44. Akishita, M., et al. 1999. Expression of the AT2 receptor developmentally programs extracellular signal-regulated kinase activity and influences fetal vascular growth. J. Clin. Invest. 103:63-71.

45. Okamoto, H., Yayama, K., Shibata, H., Nagaoka, M., and Takano, M. 1998. Kininogen expression by rat vascular smooth muscle cells: stimulation by lipopolysaccharide and angiotensin II. Biochim. Biophys. Acta. 1404:329-337.

46. Stoll, M., et al. 1995. The angiotensin AT2-receptor mediates inhibition of cell proliferation in coronary endothelial cells. J. Clin. Invest. 95:651-657.

47. Pueyo, M.E., N'Diane, N., and Michel, J.B. 1996. Angiotensin II-elicited signal transduction via AT1 receptor in endothelial cells. Br. J. Pharmacol. 118:79-84.

48. Tallant, E.A., Lu, X., Weiss, R.B., Chappel, M.C., and Ferrario, C.M. 1997. Bovine aortic endothelial cells contain an angiotensin (1-7) receptor. Hypertension. 29:388-393.

49. Mineo, C., Schimizu, H., Takada, K.I., Imanaka, Z., and Takano, T. 1994. Angiotensin II binding activity in cultured porcine arterial endothelial cells. Biochem. Pharmacol. 48:1993-1995.

50. Matsubara, H., et al. 1998. Cellular localization of angiotensin type 1 and type 2 receptor mRNAs in human renal cortex using in situ hybridization. Nephron. 80:25-34.

51. Lauar, N., and Bhoola, K. 1986. Release of tissue kallikrein from the isolated perfused kidney. Adv. Exp. Med. Biol. 198:347-354.

52. MacDonald, R.J., Southard-Smith, E.M., and Kroon, E. 1996. Disparate tissue-specific expression of members of the tissue kallikrein multigene family of the rat. J. Biol. Chem. 271:13684-13690.

53. Berk, B.C., and Corson, M.A. 1997. Angiotensin II signal transduction in vascular smooth muscle: role of tyrosine kinases. Circ. Res. 80:607-616.

54. Takahashi, E., Abe, J., and Berk, B.C. 1998. Angiotensin II stimulates p90RSK in vascular smooth muscle cells. A potential $\mathrm{Na}^{+} / \mathrm{H}^{+}$exchanger kinase. Circ. Res. 81:268-273.

55. Yang, B.C., et al. 1998. Increased angiotensin II type1 receptor expression in hypercholesterolemic atherosclerosis in rabbits. Arterioscler. Thromb. Vasc. Biol. 18:1433-1439.

56. Nakajima, M., et al. 1995. The angiotensin II type 2 (AT2) antagonizes the growth effects of the AT1 receptor: gain-of-function study using gene transfer. Proc. Natl. Acad. Sci. USA. 82:10663-10667. 